\title{
DEVELOPMENT AND TESTING A NEW TECHNOLOGY FOR PRODUCTION OF CHRYSANTHEMUMS PLANTING MATERIAL (CHRYSANTHEMUM s.l.)
}

\author{
$\underline{\text { Ana COJOCARIU }}^{1 *}$, Cătălin TĂNASE ${ }^{2}$ \\ 1 “Alexandru Ioan Cuza” University of Iaşi - “Anastasie Fătu” Botanical Garden, \\ Dumbrava Roşie Street no. 7-9, 700487 Iaşi - Romania \\ ${ }^{2}$ Department of Biology, Faculty of Biology, "Alexandru Ioan Cuza” University of Iaşi, 20A Carol I, \\ 700505 Iaşi - Romania \\ *Corresponding author. E-mail: ana.cojocariu@uaic.ro
}

\begin{abstract}
Chrysanthemums represent an important horticultural segment with uses in the autumnal to winter season, aesthetically extending the capitalization of urban open spaces. Propagation by cuttings at Chrysanthemum is the most convenient method of vegetative multiplication. There is, however, a great variability in the ability to form adventitious roots and regenerate new individuals by cuttings. Some cultivars are relatively easy to multiply by cuttings, and other species have a low capacity to rooting. In the present paper we focused on researches regarding the propagation of chrysanthemums $\left(\mathrm{a}_{1}-\right.$ Chrysathemum indicum, $\mathrm{a}_{2}-$ Chrysanthemum $\times$ grandiflorum) by new type of cuttings (stem fragment with one leaf and axillary bud - SFLAB, $b_{2}$ ) and on the evaluation of the capacity of rooting, given the increasing demand for floral planting material as a result of the development of landscape design interest in public spaces but especially private one. The main objective was to establish the influence of the cuttings characteristics (type of cuttings, with two variants $-b_{1}$-control, top stem fragment TSF; and $b_{2}$, stem fragment with one leaf and axillary bud - SFLAB) on the rooting process and the length of developed roots in four variants of rooting substrate $\left(c_{1}-c_{4}\right)$ for both types of proposed Chrysanthemum cuttings $\left(\mathrm{b}_{1}-\mathrm{b}_{2}\right)$.
\end{abstract}

Keywords: Chrysathemum, cuttings, rooting substrate, stem fragment with one leaf and axillary bud - SFLAB, top stem fragment - TSF.

\section{Introduction}

Chrysanthemum growers are obvious interested to use low cost techniques whenever possible in their crop production. Modern technologies does not reduce the risk of producing non-compliant planting material nor the risk of contamination by viral and bacterial diseases, if certain procedures are not strictly followed. Chrysanthemum growers need to know the key practices for alternative multiplication methods to make good choices in their production planning.

In the last years have been conducted studies at many species in order to speed up the process of rhizogenesis, especially by using the induction of rhizogenesis with different chemicals (growth or rooting regulators). There are a number of factors such as the type of cuttings, rooting substrate, season, pre-treatments with growth regulators and also environmental conditions (such as temperature, light and humidity) that have been reported to influence successful rooting of Chrysanthemum s.l.

In Romania, fewer studies have been conducted on chrysanthemums regarding alternative ways of multiplication and the conditions that influence multiplication, but quite 
number of studies refer to biometric, morpho-anatomic aspects, also to some modern directions aimed at in vitro propagation of chrysanthemums [LAZĂR \& CACHIŢĂ-COSMA, 1982; LAZĂR \& al. 1981; PETRUŞ-VANCEA \& CACHIŢĂ-COSMA, 2013]. So far, there are a lot of published reviews related to the Chrysanthemum biotechnology [ROUT \& DAS, 1997; TEIXEIRA DA SILVA, 2003, 2004; SHINOYAMA \& al. 2006; TEIXEIRA DA SILVA $\&$ al. 2013]. However, many new studies are published every year. By better understanding of the ornamental chrysanthemum biotechnology (traditional propagation, mutation reproduction or transgenic technologies), new types of plants could be generated: with high resistance to biotic stress (diseases and pests) and abiotic (temperature, salinity, water stress, etc.), or plants for cut flowers with a longer life after harvesting and thus better storage capacity, new colors for flowers, new leaf shapes or architecture [TEIXEIRA DA SILVA \& al. 2013].

At dicotyledonous species, adventitious roots can be defined as roots that can develop under specific conditions, from organs such as leaves and stems. The formation of adventitious roots (AR) in the cuttings from top stem fragments, is a physiological key process in the propagation of many species of ornamental plants. Despite the intensive control on environmental factors in the modern ornamental plant propagation industry, significant economic losses continue to occur as a result of insufficient rooting [LIU \& al. 2013]. Chrysanthemums (Chrysanthemum s.l.) have significant ornamental value and thus have great economic importance, being also subjected to losses due to insufficient rooting of young shoots, the main method of vegetative propagation practiced in this culture. Insufficient understanding of the mechanisms that control adventitious root formation prevents the use of reliable technologies to improve the percentage of adventitious root development in ornamental plant cuttings in general.

Adventitious rooting is a quantitative trait of a genetic nature that is affected by several endogenous but also environmental (exogenous) factors. One of the endogenous factors with a key role in controlling AR formation is auxin. Many authors have shown that auxin has the ability to initiate AR formation. PAGNUSSAT \& al. (2002) demonstrated that nitric oxide mediates the auxin response that results in AR formation in cucumber, and LIAO $\&$ al. (2010) studied the role of nitric oxide in the process of AR formation in Chrysanthemum. The progressive accumulation and local concentration of auxin at the base of the cuttings seems to be important for initiating the rooting process [ACOSTA \& al. 2009]. There is growing evidence that AR formation also depends on the action of ethylene [CLARK $\&$ al. 1999; SHIBUYA \& al. 2004], which occurs as a result of the injury of the vegetal tissue in the process of making the cuttings and has been studied in a large number of species of ornamental plants or of industrial value. The response of the plant to the injury produced by the cut applied to the stem is a necessary step in the process of forming AR [DA COSTA \& al. 2013]. Once the stem has been excised from the mother plant, it must redistribute the remaining resources as soon as possible, to form adventitious roots and restore the physiological balance, which allows the transfer of resources between the different parts of the seedling, and some research has shown that the distribution of carbohydrates in detached cuttings may be more important than the content itself in such substances [RUEDELL \& al. 2013].

Traditional methods of propagation are no longer able to respond to growing market demands and to meet new consumer demands, so new biotechnological methods must be applied. Biotechnology includes areas of study such as in vitro culture and micropropagation, cryopreservation, molecular technologies, genetic transformation, synthetic seed technology, 
secondary metabolism and acclimatization, and so far many studies have been published on the biotechnology of ornamental chrysanthemums.

The main purpose of the research is to improve production technology of chrysanthemum cuttings, in order to increase the efficiency of planting material production by a higher percentage of rooted cuttings and by a new quality planting material. The new methods proposed in the research in order to obtain chrysanthemum seedlings by testing the economic yield in the field, could lead to a decrease in total production costs, but also a quantitative reduction of the plant stock material used for propagation, with the unaltered maintenance of the quantitative yield for the final plant material.

\section{Material and methods}

Plant materials and growing conditions. The experimental field was set at "Anastasie Fatu" Botanical Garden belonging to "Alexandru Ioan Cuza" University of Iasi, Romania, in the heated greenhouses compartments and were used two Chrysanthemum cultivars from institution Collection - Chrysanthemum indicum L. cv. Carmina, noted in our research as $\left(\mathrm{I}, \mathrm{a}_{1}\right)$ and Chrysanthemum $\times$ grandiflorum Ramat. cv. Yellow Stardust (II, $\left.\mathrm{a}_{2}\right)$ [The Plant List, 2014; The Plant List, 2014a]. The cuttings were set about February 15, collected from stock-plants - Figure 1, maintained in a vegetative stage, in cold greenhouses with a main temperature of $13.8^{\circ} \mathrm{C}$ and with moderate irrigation once for a week.
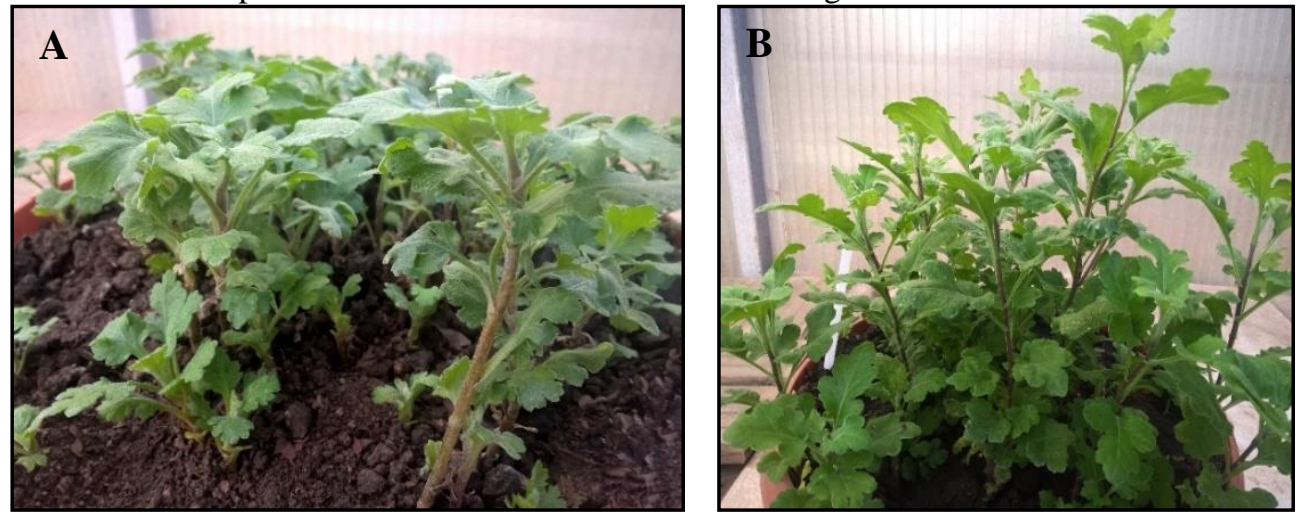

Figure 1. Stock-plants of Chrysanthemum, A. a1 Cv. I - Chrysanthemum indicum 'Carmina',

B. $a_{2}$ Cv. II - Chrysanthemum x grandiflorum 'Yellow Stardust' (details on vegetative shoots)

\section{Experimental Model}

For the proposed research, was organized a multifactorial experiment that included three factors $(\mathrm{a}, \mathrm{b}, \mathrm{c})$. Multifactorial experiments are characterized by the fact that the same experiment studies the simultaneous influence of several factors and has the advantage of highlighting the interactions between such a different factors.

The type of chosen experiment was tri-factorial, type 2(a)x2(b)x4(c) - Figure 2. The studied factors were: factor A - the chrysanthemum cultivar, with two graduations, $\mathrm{a}_{1}$ : I Chrysanthemum indicum 'Carmina' $\mathrm{a}_{2}$ : II - Chrysanthemum $\times$ grandiflorum 'Yellow Stardust'; Factor B - the type of cutting, with two graduations, $b_{1}$ : top stem fragment - TSF, control and $\mathrm{b}_{2}$ : stem fragment with one leaf and axillary bud - SFLAB; Factor C - the type of rooting substrate with four graduations, $\mathrm{c}_{1}: \mathrm{pt}-$ peat $(100 \%), \mathrm{c}_{2}: \mathrm{pt}+\mathrm{p}-$ peat+perlite $(\mathrm{v} / \mathrm{v})$, 
$\mathrm{c}_{3}: \mathrm{pt}+\mathrm{p}+\mathrm{s}-$ peat+perlite+sand $(\mathrm{v} / \mathrm{v} / \mathrm{v}), \mathrm{c}_{4}: \mathrm{p}$ - perlite $(100 \%)$. Thus, from the combination of factors and their graduations, 16 experimental variants resulted, and for each experimental variant, 25 cuttings were made, with a total of 400 cuttings per experiment. The control variant (standard or control $-b_{1}$ ) is the variant that served as the basis of comparison for the other variants researched in the experiment.

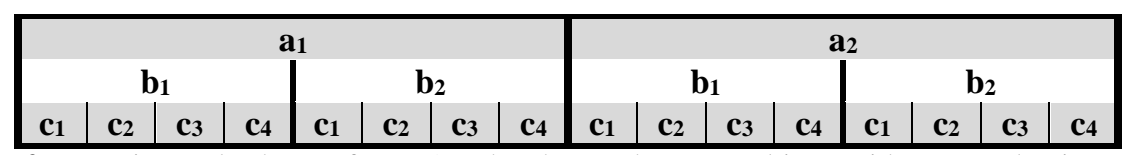

Figure 2. Experimental scheme: factor $\mathrm{A}$ - the chrysanthemum cultivar, with two graduations, $\mathrm{a}_{1}$ and a2; factor B - the type of cutting, with two graduations, $\mathrm{b}_{1}$ and $\mathrm{b}_{2}$; factor $\mathrm{C}$ - the type of rooting substrate with four graduations, $\mathrm{c}_{1}, \mathrm{c}_{2}, \mathrm{c}_{3}$ and $\mathrm{c}_{4}$.

Sampling of chrysanthemum cuttings. In chrysanthemum crops, as a classical (control) manner, the cuttings are made from shoots that develop at the base of the stockplants and are harvested when they are $8-10 \mathrm{~cm}$ long (Figure 3, A). Choosing healthy stockplants is essential, and in order to reach the objectives of the present study, special attention was given to respecting their length at harvest (including the number of leaves), in order to maintain the experimental characteristics with at least 9 leaves on each vegetative shoot.

The two types of cuttings were made differently, according to the proposed experimental scheme:

TSF: represents the classic type of cuttings used in the vegetative propagation of chrysanthemums, respectively cuttings from the top of the shoots - top stem fragment (Figure $3, \mathrm{~B})$. For the interpretations related to the influence of the type of cuttings on the rooting and obtaining of planting material, this type of cuttings represented the control and provided comparative data to establish the efficiency of the proposed new method for cuttings.

The TSF cuttings are made after a period when the stock-plants were forced, providing temperatures of $8-10-12{ }^{\circ} \mathrm{C}$, normal aeration, lightning and watering, in order to start into vegetation. A shoot should be with 9-10 leaves, and 8-10 cm long (Figure 3, A). The first pairs of leaves are suppressed and only 3-4 leaves are left on the top, after which a cut with the scissors or the sharp knife under a node or oblique through the node is executed. The remaining leaves at the top are reduced by pinching, if the cuttings are very vigorous. In the end, a TSF cutting had a length of 5-6 cm, which provides at the base a minimum area of $2.5 \mathrm{~cm}$ for mounting in the rooting substrate, and at the top 3-4 cm for supporting the metabolic processes through the foliar apparatus (Figure 3, B).

SFLAB: represents a new type of proposed cutting for the experiment, made as a single-node stem fragment, with the corresponding leaf of the node, at least until the emergence of the new shoots developed from the axillary buds (Figure 4, A, B) - stem fragment with one leaf and axillary bud (SFLAB). The execution of such a cuttings is made by two cuts made on the stem, oblique, above and below the node (Figure 4, A), obtaining a fragment of the stem with a length of about $1 \mathrm{~cm}$, having a corresponding node and leaf, with axillary buds intact.

As experimental sub-variants, we considered the achievement of 9 SFLAB cuttings from a single harvested shoot, marking three levels of leaf development, with different degree of stem maturation (Figure 4, B):

- Lower level (INF) - at the base of the shoot: 3 harvested SFLAB cuttings (1-3)

- Medium level (MED) - 3 harvested SFLAB cuttings (4-6)

- Upper level (SUP) - at the top of the stem: 3 harvested SFLAB cuttings (7-9). 
The shaping of the SFLAB cuttings in both variants requires greater attention in terms of hygiene of the work, the working tools being periodically cleaned and disinfected, and the maneuvering space of the periodic vegetal material cleaned by removing the obtained vegetal debris.

The purpose of testing the second type of cuttings (SFLAB) is to verify the improvement of the yield of cuttings in chrysanthemums, in order to increase the number of cuttings that can be made from a single shoot: a single cuttings in the case of the control variant (TSF) and 9 cuttings for the proposed variant (SFLAB).

\section{Observations, measurements and determinations}

The parameterization of the qualitative and quantitative characteristics of the cuttings in the two varieties of chrysanthemums taken in the study consisted in making the following observations and measurements: observations on the degree of survival and the percentage of rooting of chrysanthemum cuttings; measurements on the aerial (vegetative) system of cuttings - height of cuttings (cm), measured at 4, 6, 8 weeks (W4, W6, W8), number of leaves developed per seedling, at 4, 6, 8 weeks (W4, W6, W8); measurements and observations on the root system of the cuttings - the total length of the developed roots/cuttings $(\mathrm{cm})$, roots density $\left(\mathrm{m} / \mathrm{m}^{3}\right)$, display and observations on the root architecture of chrysanthemum cuttings; observations to establish the days for development of new shoots formed from the axillary buds of the leaf, at the SFLAB cuttings.

\section{Mathematical and statistical models for results interpretation}

Within the experiment, for the determinations related to root length, the root system of chrysanthemum cuttings was taken from all 400 samples corresponding to the experimental variants. Only roots with a diameter below $2 \mathrm{~mm}$ were sorted by direct calibration, cleaned by water washing and examined in transparent Petri dishes on millimeter paper. The distribution of removed roots based on the exceeded diameter $(>2 \mathrm{~mm})$ was not quantitatively determined, but all the root samples examined included a typical root diameter range $(0.1$ to $2.0 \mathrm{~mm})$. The root samples contained all types of roots, including suberized, unsubstituted, secondary thickened and lateral, as long as they respected the required diameter limit and were left as complete as possible [GOUBRAN \& RICHARDS, 1979].

The roots were washed under water to remove adherent substrate particles and spread on laminated sheets of millimeter paper (A4 or A3 size). Thus, the roots were examined and the data were noted by evaluating the dimensions of the displaying zone and area determination, counting the vertical and horizontal lines taken into account, scoring the lengths of the background system lines, counting the intersections between the roots of the cuttings and the system of background lines. These data were inserted into tables to further facilitate the calculation of the total root length using Newman calculation formula.

The statistical methods were based on the experimental data obtained and which represent the numerical results of the experimental research. The data obtained during the experiment were noted in the centralization tables, on the basis of which several distribution functions were calculated. For the values obtained in the quantitative and qualitative biometric measurements (the height of the cuttings, the number of leaves, the length of the roots, the density of the roots) the average values were calculated based on the recordings for all 25 repetitions (cuttings) per experimental variant. Also, in order to appreciate the uniformity of the studied variants, the standard deviation (SD) of the obtained average was calculated. For roots density determination (D), the root length was reported at a given substrate volume, i.e. $60 \mathrm{ml}\left(0.06 \mathrm{~m}^{3}\right)$, the results being expressed in $\mathrm{m} / \mathrm{m}^{3}$. Formula used in the calculation [ALI, 2010]: Root density (D) = total root length / substrate volume. 

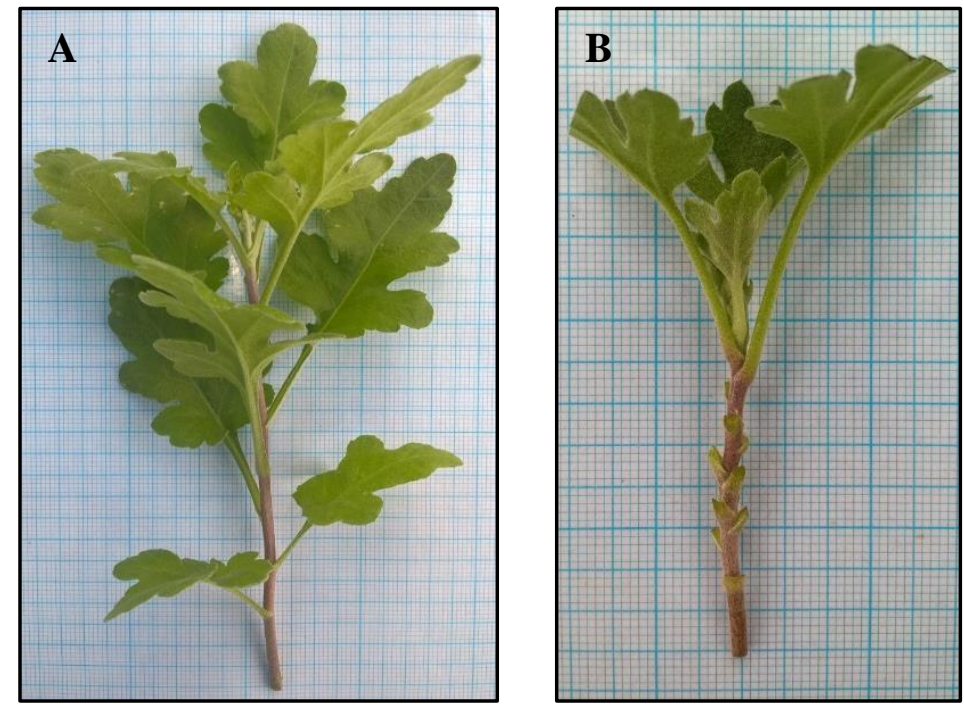

Figure 3. A - Shoot top fragment with minimum 9 leaves, sampled for Chrysanthemum cuttings, $\mathbf{B}-\mathrm{b}_{1}$ type of cuttings - control, top stem fragment - TSF
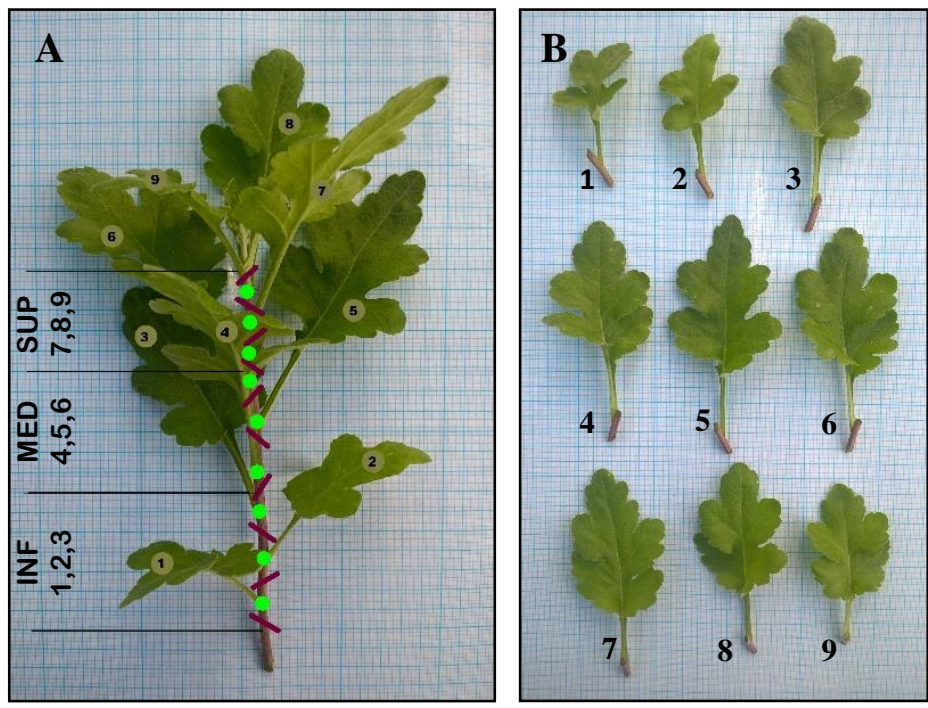

Figure 4. A - Method of making $\mathrm{b}_{2}$ cuttings variant (stem fragment with one leaf and axillary bud - SFLAB), B - SFLAB cuttings, indicating sampling level, lower (1-3), medium (4-6) or higher (7-9) 


\section{Results and discussions}

The observations were made during the experiment period (45 days) at equal time intervals, respectively at 7 days (W1-W6), following a series of elements such as: the number of rooted cuttings, the number of compromised cuttings, the percentage of losses, the total rooting percentage by type of cuttings (Table 1).

Table 1. Rooting percentage (W6) - chrysanthemum cuttings (TSF and SFLAB), by substrate type and cultivar

\begin{tabular}{|c|c|c|c|c|c|c|c|c|c|}
\hline \multirow{3}{*}{$\begin{array}{l}\text { Total no. of cuttings } / \\
\quad \text { variant }=25\end{array}$} & \multicolumn{8}{|c|}{ TSF } & \multirow{3}{*}{$\begin{array}{l}\text { Total no. of } \\
\text { cuttings }\end{array}$} \\
\hline & \multicolumn{2}{|c|}{ pt } & \multicolumn{2}{|c|}{$\mathbf{p t + p}$} & \multicolumn{2}{|c|}{$p t+p+s$} & \multicolumn{2}{|c|}{ p } & \\
\hline & I & II & I & II & I & II & I & II & \\
\hline rooted cuttings (no.) & 25 & 25 & 25 & 25 & 24 & 25 & 25 & 25 & \multirow{4}{*}{200} \\
\hline rooting percent $(\%)$ & 100 & 100 & 100 & 100 & 96 & 100 & 100 & 100 & \\
\hline compromised cuttings (no.) & 0 & 0 & 0 & 0 & 1 & 0 & 0 & 0 & \\
\hline losses percent $(\%)$ & 0 & 0 & 0 & 0 & 4 & 0 & 0 & 0 & \\
\hline \multicolumn{9}{|c|}{ total percentage rooted cuttings $-\mathrm{TSF}$} & $99,5 \%$ \\
\hline & \multicolumn{8}{|c|}{ SFLAB } & \multirow{3}{*}{$\begin{array}{l}\text { Total no. of } \\
\text { cuttings }\end{array}$} \\
\hline & \multicolumn{2}{|c|}{ pt } & \multicolumn{2}{|c|}{ pt+p } & \multicolumn{2}{|c|}{$\mathrm{pt}+\mathrm{p}+\mathrm{s}$} & \multicolumn{2}{|c|}{$\mathbf{p}$} & \\
\hline & I & II & $\mathbf{I}$ & II & I & II & I & II & \\
\hline rooted cuttings (no.) & 25 & 21 & 23 & 23 & 25 & 25 & 25 & 24 & \multirow{4}{*}{200} \\
\hline rooting percent (\%) & 100 & 84 & 92 & 92 & 100 & 100 & 100 & 96 & \\
\hline compromised cuttings (no.) & 0 & 4 & 2 & 2 & 0 & 0 & 0 & 1 & \\
\hline losses percent $(\%)$ & 0 & 16 & 8 & 8 & 0 & 0 & 0 & 4 & \\
\hline \multicolumn{9}{|c|}{ total percentage rooted cuttings - SFLAB } & $95,5 \%$ \\
\hline
\end{tabular}

Abbreviations: I - Chrysanthemum indicum 'Carmina', II - Chrysanthemum $\times$ grandiflorum 'Yellow Stardust', TSF - top stem fragment, SFLAB - stem fragment with one leaf and axillary bud, $\mathbf{p t}$ - peat $(100 \%), \mathbf{p t}+\mathbf{p}$ - peat+perlite $(\mathrm{v} / \mathrm{v}), \mathbf{p t}+\mathbf{p}+\mathbf{s}-$ peat+perlite+sand $(\mathrm{v} / \mathrm{v} / \mathrm{v}), \mathbf{p}-$ perlite $(100 \%)$.

Given the fact that at mounting of cuttings into rooting substrate, has not been used substances with effect in rhizogenesis stimulation, the total losses percentage of chrysanthemum was only 5\%. This insignificant percentage indicates that the genus Chrysanthemum s.l. has a very good capacity of rooting, even in the absence of hormonal stimulants, which are indicated for use in vegetative propagation, especially for the more difficult rooting species.

Data from the literature indicate a correlation between cultivar and rooting success of the cuttings, but with the use of IBA in different concentrations, the best results were obtained for Chrysanthemum cv. Crimson Robe, cv. Polario, cv. Escort, cv. Sterling and cv. Luysona at $50 \mathrm{ppm}$ IBA, by spraying or immersing in the root stimulator, thus obtaining a more compact root system [PETTER, 1992]. Our results obtained for the varieties of Chysanthemum indicum (I) and Chrysanthemum $\times$ grandiflorum (II) indicate a correlation between the species and the rooting capacity, of the total losses of 5\%, recorded $3.5 \%$ for cv. I ( 7 cuttings) and $1.5 \%$ for cv. II ( 7 cuttings). This difference, although insignificant could be explained by the fact that Chrysanthemum $\times$ grandiflorum - chrysanthemum for cut flower, is a complex hybrid species, less adapted to environmental variations, being cultivated only in protected spaces, while Chrysanthemum indicum, it is represented by rustic horticultural varieties with a better tolerance to variations of the environment, being successfully cultivated in open spaces.

Regarding the rooting capacity of cuttings according to the substrate, a lower rooting rate was observed for the peat and the peat+perlite substrates (96\%), while for 


\section{DEVELOPMENT AND TESTING A NEW TECHNOLOGY FOR PRODUCTION OF...}

peat+perlite+sand and perlite variants, the rate was $99 \%$. The explanation of this difference could be given by the fact that peat is a substrate that becomes quite compact, which does not allow a good circulation of water and air at the root system level, while the perlite, through the porous structure allows this process. KHER (1976) reported the coarse sand as optimum rooting medium for chrysanthemums, also based on the high capacity of drainage and aeration at the root level.

During the experiment, observations were made regarding the influence of the type of cuttings on the obtaining of planting material, with the appreciation of the yield and the comparison of the classic variant (TSF) with the proposed new method (SFLAB), but also observations related to position of the harvested node from the stem (lower, medium or higher) and rooting rate. The best survival rate of cuttings (199 cuttings rooted out of the total 200 mounted in the rooting substrate) was recorded in the case of cuttings made according to the classical method (TSF) $-99.5 \%$, so the losses in this case were insignificant. The cuttings made from the single-node stem fragment (SFLAB) have rooted in a proportion of $95.5 \%$, which represents a very good percentage indicating a higher yield for this method.

For this new technique, in comparison with the classical method, evaluations were made regarding the yield, by relating the initial used material (number of shoots harvested) to the total number of rooted cuttings obtained (Table 2). The method of chrysanthemum cuttings made from the single-node stem fragment showed a much higher yield, over $8 \%$, also appreciating that this yield could be even higher, up to $10-12 \%$ if the shoots of higher heights are used to make the cuttings, so also with a greater number of nodes on the stem. This technique could successfully answer the problem related to the amount of material from which it starts to multiply chrysanthemums, offering solutions to obtain a greater amount of planting material starting from a smaller number of stock-plants. For a production sector, the reduction of the number of stock-plants from which it starts could bring as an advantage a reduction of the storage space, respectively cold greenhouses for the rest period of the plants.

Table 2. Production efficiency of rooted cuttings at both types of cuttings

\begin{tabular}{|c|c|c|c|c|}
\hline \multirow{2}{*}{$\begin{array}{c}\text { Cutting } \\
\text { type }\end{array}$} & $\begin{array}{c}\text { Number of shoots } \\
\text { initially harvested }\end{array}$ & $\begin{array}{c}\text { Total number of } \\
\text { cuttings }\end{array}$ & $\begin{array}{c}\text { Number of rooted } \\
\text { cuttings }\end{array}$ & \multirow{2}{*}{ Yield (1:3) } \\
\hline TSF & 1 & 2 & 3 & \\
\hline SFLAB & 200 & 200 & 199 & $1,005 \%$ \\
\hline
\end{tabular}

For SFLAB cuttings we proceeded to harvest in equal proportion, from three different levels of the stem, starting from the base to the tip of the harvested shoots: lower level (INF), medium (MED) and higher (SUP). Three cuttings were harvested from each level on the same shoot, were scored accordingly and mounted on categories in the rooting substrate. The results regarding the number of cuttings rooted according to the level from which they were harvested, are presented in Table 3.

Table 3. Number of cuttings rooted according to the level from which they were collected

\begin{tabular}{|c|c|c|c|}
\hline Harvest level & Number of cuttings & Number of rooted cuttings & Percent \\
\hline INF & 32 & 26 & $81,25 \%$ \\
\hline MED & 32 & 30 & $93,75 \%$ \\
\hline SUP & $32 *+4(36)$ & $31 *+4(35)$ & $97,22 \%$ \\
\hline
\end{tabular}

It is found that for the cuttings made of stem fragments located at the top of the shoots, the rooting percentage was over $97 \%$, followed by the medium level with $93 \%$, while 
Ana COJOCARIU \& Cătălin TĂNASE

the cuttings made from the base of the shoots were rooted in proportion of $81 \%$. These differences are explained by the theories regarding the presence and circulation of hormones in plants and those related to the apical dominance, being known that auxin, responsible for the formation of adventitious roots, is found in the highest concentration in the apical part of the plant, from where it has a downward path [ACOSTA \& al. 2009]. At chrysanthemums, JOHTI \& al. (1987) reported the influence of the stem type on the rooting, with reference to the origin, from basal shoots $(95.85 \%)$ or from the stem tip of the vegetative growth period $(82.5 \%)$, and thus reported a higher yield for cuttings and shoots grown at the base.

There are few bibliographic references regarding the type of cuttings and especially those made from the single-node stem fragment (SFLAB), in chrysanthemums, SINGH \& CHETTRI (2013) conducting an experiment to test a new method of multiplication, using cuttings formed from the leaf with the axillary buds and the stem fragment, also using root stimulators (IBA and kinetin). Thus, they identified the method as effective, especially in terms of the complexity of the procedure, the time required and the efficiency of using the initial plant material.

In order to appreciate the interval required for the development of new shoots from the axillary buds at SFLAB cuttings, observations were made regarding the day when they became visible, starting with the second week of experiment. After the new shoots developed a minimum of 4 leaves, the leaf was removed from the initial stem to stimulate their independent development (Table 4, Figure 5).

Table 4. Duration of rooting at SFLAB cuttings of chrysanthemums, expressed in number of days to shoot emergence of axillary bud leaf - Chrysanthemum indicum 'Carmina' (I) and Chrysanthemum $\times$ grandiflorum 'Yellow Stardust' (II)

\begin{tabular}{|c|c|c|c|c|}
\hline \multirow{2}{*}{$\mathbf{I}$} & pt & pt+p & $\mathrm{pt}+\mathrm{p}+\mathrm{s}$ & p \\
\hline & \multicolumn{4}{|c|}{ Number of days to shoot emergence of axillary bud leaf } \\
\hline $\mathbf{A}$ & $21 \pm \mathrm{SD}$ & $16 \pm \mathrm{SD}$ & $18 \pm \mathrm{SD}$ & $15 \pm \mathrm{SD}$ \\
\hline *SD & $* 7,25$ & $* 2,94$ & $* 7,33$ & $* 5,19$ \\
\hline \multirow{2}{*}{ II } & pt & $\mathbf{p t}+\mathbf{p}$ & $\mathrm{pt}+\mathbf{p}+\mathbf{s}$ & $\mathbf{p}$ \\
\hline & \multicolumn{4}{|c|}{ Number of days to shoot emergence of axillary bud leaf } \\
\hline $\mathbf{A}$ & $21 \pm \mathrm{SD}$ & $24 \pm \mathrm{SD}$ & $27 \pm \mathrm{SD}$ & $24 \pm \mathrm{SD}$ \\
\hline *SD & $* 4,47$ & $* 5,84$ & $* 5,99$ & $* 5,19$ \\
\hline \multicolumn{5}{|c|}{$\begin{array}{l}\text { Abbreviations: A - Average, SD - Standard Deviation, pt - peat }(100 \%), \mathbf{p t}+\mathbf{p}-\text { peat }+ \text { perlite }(\mathrm{v} / \mathrm{v}), \mathbf{p t}+\mathbf{p}+\mathbf{s}- \\
\text { peat+perlite+sand }(\mathrm{v} / \mathrm{v} / \mathrm{v}), \mathbf{p}-\text { perlite }(100 \%) .\end{array}$} \\
\hline
\end{tabular}

Figure 5. New shoots developed from the axillary buds of the leaf. A. Chrysanthemum indicum 'Carmina' (I), B. Chrysanthemum $\times$ grandiflorum 'Yellow Stardust' (II) 


\section{DEVELOPMENT AND TESTING A NEW TECHNOLOGY FOR PRODUCTION OF...}

Observations related to the type of cuttings (Table 5), highlighted that by the classical method (control) with cuttings from the top of the stem, more vigorous cuttings are obtained, in both studied horticultural varieties, regarding both the number of developed leaves, as well as the height of the cuttings. This aspect is explained by the fact that the TSF cuttings start from an advanced stage, with vegetative part already developed and which supports the growth even to the adventitious root formation, while the SFLAB cuttings require a longer time until the new shoots are able to independently support the physiological processes of the rooted cuttings. However, in the case of SFLAB cuttings there is a greater uniformity of the development of cuttings, the standard deviation (SD) varying in the range $0.38-1.44$, while for TSF cuttings in the range 0.55-2.18. At Chrysanthemum indicum 'Carmina', the highest average value of the number of leaves formed was recorded for TSF cuttings in peat substrate $100 \%-9.12$ leaves as average, and the lowest value was for perlite (average 7 leaves). In SFLAB cuttings, the minimum value recorded in TSF cuttings (7) was not exceeded, the average number of leaves being between 4.8 and 6.39. In height, the same tendency was maintained, for the TSF variant with the average height of the cuttings between 3.21 and $4.46 \mathrm{~cm}$, while for the SFLAB cuttings the average values of the height of the cuttings were between 1.61 and $3.13 \mathrm{~cm}$. Compared to the cv. Carmina, in Chrysanthemum $\times$ grandiflorum 'Yellow Stardust' there were higher values of the height of the cuttings, but smaller for the number of leaves formed. The TSF cuttings showed an advantage over the number of leaves formed (7.28-8.84) compared to the SFLAB cuttings (4.04-4.47), and as the height was registered the same tendency (TSF cuttings with height in the range $2.88-6.03 \mathrm{~cm}$, and SFLAB cuttings in the range $1.64-2.52 \mathrm{~cm}$.

Table 5. Number of developed leaves and height of TSF and SFLAB cuttings [W6] - Chrysanthemum indicum 'Carmina' (I) and Chrysanthemum $\times$ grandiflorum 'Yellow Stardust' (II)

\begin{tabular}{|c|c|c|c|c|}
\hline \multirow{2}{*}{ I, TSF } & pt & $\mathbf{p t}+\mathbf{p}$ & $\mathrm{pt}+\mathrm{p}+\mathrm{s}$ & p \\
\hline & \multicolumn{4}{|c|}{ Number of developed leaves [W6] } \\
\hline $\mathbf{A}$ & $9,12 \pm \mathrm{SD}$ & $9,68 \pm \mathrm{SD}$ & $9,24 \pm \mathrm{SD}$ & $7 \pm \mathrm{SD}$ \\
\hline \multirow[t]{2}{*}{ *SD } & $* 1,76$ & $* 1,46$ & $* 2,18$ & $* 1,12$ \\
\hline & \multicolumn{4}{|c|}{ Cutting height - $\mathrm{cm}$ [W6] } \\
\hline $\mathbf{A}$ & $4,22 \pm \mathrm{SD}$ & $4,46 \pm \mathrm{SD}$ & $4,2 \pm \mathrm{SD}$ & $3,21 \pm \mathrm{SD}$ \\
\hline *SD & $* 1,03$ & $* 0,78$ & $* 0,55$ & $* 0,57$ \\
\hline I, SFLAB & \multicolumn{4}{|c|}{ Number of developed leaves [W6] } \\
\hline $\mathbf{A}$ & $5,64 \pm \mathrm{SD}$ & $6,39 \pm \mathrm{SD}$ & $6,09 \pm \mathrm{SD}$ & $4,8 \pm \mathrm{SD}$ \\
\hline \multirow[t]{2}{*}{$*$ SD } & $* 1,38$ & $* 1,30$ & $* 1,44$ & $* 0,87$ \\
\hline & \multicolumn{4}{|c|}{ Cutting height $-\mathrm{cm}$ [W6] } \\
\hline $\mathbf{A}$ & $2,54 \pm \mathrm{SD}$ & $3,04 \pm \mathrm{SD}$ & $3,13 \pm \mathrm{SD}$ & $1,61 \pm \mathrm{SD}$ \\
\hline *SD & $* 0,72$ & $* 0,88$ & $* 0,96$ & $* 0,65$ \\
\hline II, TSF & \multicolumn{4}{|c|}{ Number of developed leaves [W6] } \\
\hline $\mathbf{A}$ & $8,84 \pm \mathrm{SD}$ & $8,08 \pm \mathrm{SD}$ & $7,96 \pm \mathrm{SD}$ & $7,28 \pm \mathrm{SD}$ \\
\hline \multirow[t]{2}{*}{ *SD } & $* 1,21$ & $* 1,12$ & $* 1,14$ & $* 1,06$ \\
\hline & \multicolumn{4}{|c|}{ Cutting height $-\mathrm{cm}$ [W6] } \\
\hline $\mathbf{A}$ & $6,03 \pm \mathrm{SD}$ & $5,01 \pm \mathrm{SD}$ & $5,25 \pm \mathrm{SD}$ & $2,88 \pm \mathrm{SD}$ \\
\hline *SD & $* 0,97$ & $* 1,04$ & $* 0,85$ & $* 0,42$ \\
\hline II, SFLAB & \multicolumn{4}{|c|}{ Number of developed leaves [W6] } \\
\hline $\mathbf{A}$ & $4,47 \pm \mathrm{SD}$ & $4,39 \pm \mathrm{SD}$ & $4,04 \pm \mathrm{SD}$ & $4,20 \pm \mathrm{SD}$ \\
\hline \multirow[t]{2}{*}{ *SD } & $* 0,87$ & $* 0,89$ & $* 0,89$ & $* 0,78$ \\
\hline & \multicolumn{4}{|c|}{ Cutting height $-\mathrm{cm}$ [W6] } \\
\hline $\mathbf{A}$ & $2,52 \pm \mathrm{SD}$ & $1,89 \pm \mathrm{SD}$ & $1,64 \pm \mathrm{SD}$ & $1,97 \pm \mathrm{SD}$ \\
\hline *SD & $* 0,73$ & $* 0,59$ & $* 0,38$ & $* 0,44$ \\
\hline
\end{tabular}




\section{Ana COJOCARIU \& Cătălin TĂNASE}

A proposed step in the production of planting material was the transplanting of rooted cuttings to $9 \mathrm{~cm}$ diameter pots (Figure 6, A), using another soil mix, in equal proportions peat and leaf soil (1:1). This step was required to analyze the growth rate of chrysanthemum cuttings after rooting, in order to obtain high quality plant material, but also to observe the reaction of cuttings made by the two methods (TSF and SFLAB) in order to evaluate the final production of cuttings, both quantitatively and especially qualitatively.
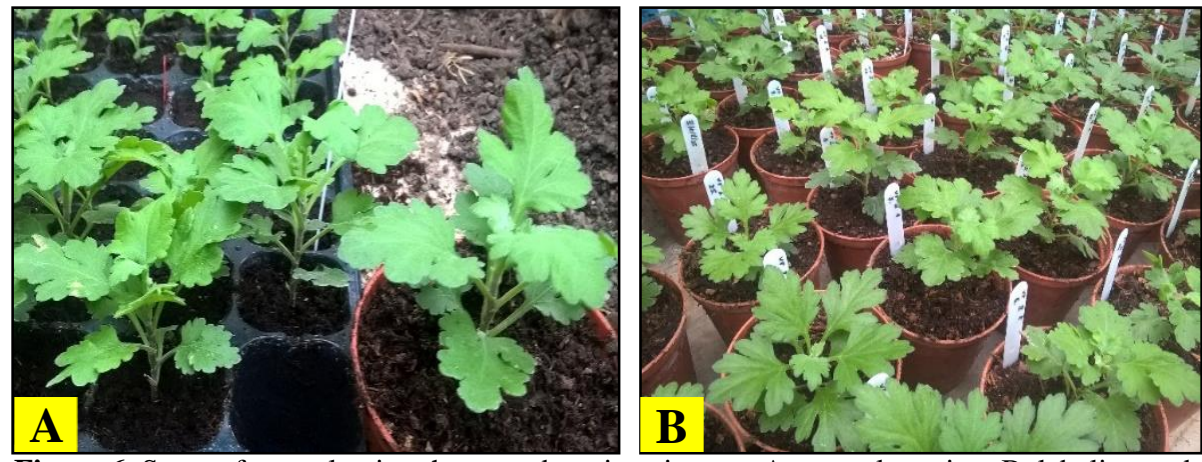

Figure 6. Stage of transplanting the rooted cuttings in pots, A. transplantation, B. labeling and the general aspect of the cuttings after transplanting

In the case of the SFLAB cuttings (Table 6), it is noticed the improvement of the growth rate, by accelerating the formation of new leaves and elongating the transplanted cuttings in increased volume of the substrate and improved composition. The standard deviation indicates the uniformity of the lots (values in the range 0.41-1.08) - Figure 6, B, which also shows that the cuttings obtained in different variants of substrate, including those rooted in variants of inorganic substrate (100\% perlite), can recover the growth rate after transplanting them into a mixture of peat with leaf soil.

Table 6. The growth rate of the cuttings in pots after transplantation (SFLAB), the number of leaves and the height of the cuttings [difference W8-W6] - Chrysanthemum indicum 'Carmina' (I) and Chrysanthemum $\times$ grandiflorum 'Yellow Stardust' (II)

\begin{tabular}{|c|c|c|c|c|}
\hline & pt & pt+p & $\mathrm{pt}+\mathrm{p}+\mathrm{s}$ & p \\
\hline I & \multicolumn{4}{|c|}{ number of leaves [DIF. W8-W6] } \\
\hline A & $4,52 \pm \mathrm{SD}$ & $4,52 \pm \mathrm{SD}$ & $4,92 \pm \mathrm{SD}$ & $2,8 \pm \mathrm{SD}$ \\
\hline *SD & $* 0,91$ & $* 1,08$ & $* 0,95$ & $* 0,82$ \\
\hline & \multicolumn{4}{|c|}{ height of the cuttings [DIF. W8-W6] } \\
\hline $\mathbf{A}$ & $5,19 \pm \mathrm{SD}$ & $3,91 \pm \mathrm{SD}$ & $3,97 \pm \mathrm{SD}$ & $3,66 \pm \mathrm{SD}$ \\
\hline *SD & $* 0,60$ & $* 0,46$ & $* 0,60$ & $* 0,41$ \\
\hline II & \multicolumn{4}{|c|}{ number of leaves [DIF. W8-W6] } \\
\hline $\mathbf{M}$ & $3,71 \pm \mathrm{SD}$ & $3,82 \pm \mathrm{SD}$ & $2,88 \pm \mathrm{SD}$ & $3,20 \pm \mathrm{SD}$ \\
\hline *SD & $* 0,56$ & $* 0,72$ & $* 0,72$ & $* 0,72$ \\
\hline & \multicolumn{4}{|c|}{ height of the cuttings [DIF. W8-W6] } \\
\hline M & $4 \pm \mathrm{SD}$ & $3,15 \pm \mathrm{SD}$ & $4,21 \pm \mathrm{SD}$ & $3,56 \pm \mathrm{SD}$ \\
\hline *SD & $* 0,57$ & $* 0,49$ & $* 0,67$ & $* 0,42$ \\
\hline
\end{tabular}


Observations made in experimental plots of chrysanthemum cuttings transplanted was continued until planting them in permanent place (May, 2018), in the field for the first variety - Chrysanthemum indicum 'Carmina', or protected greenhouses for the second variety - Chrysanthemum $\times$ grandiflorum 'Yellow Stardust'. Overall, the plants obtained as planting material showed a clear uniformity, regardless of the type of cuttings from which they were obtained (TSF or SFLAB) - Figure 7, 8. These observations allowed to recommend the use of the method with SFLAB cuttings, because vigorous plants can be obtained, a production yield of more than $8 \%$, with the mention that it is possible to qualitatively increase the material produced by introducing the intermediate stage of transplanting to larger pots after rooting.

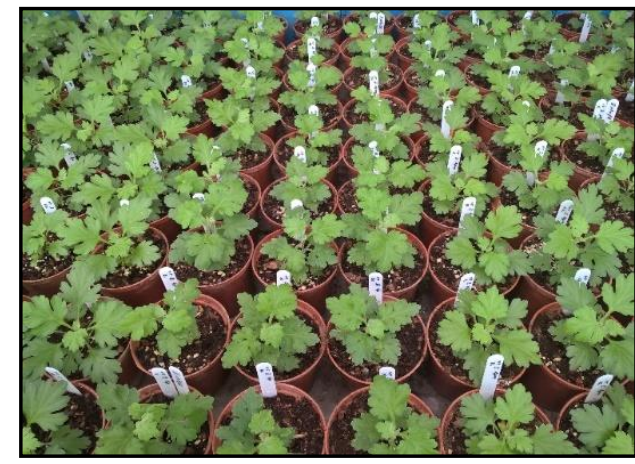

Figure 7. General aspect of experimental field, two weeks after transplantation (W8)

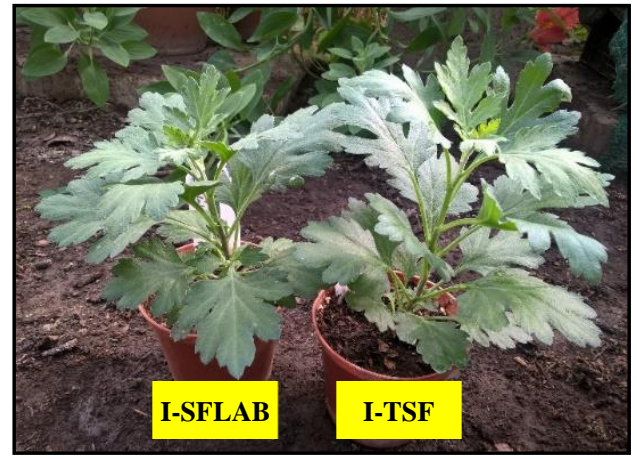

Figure 8. Form of plants obtained after transplanting, before planting in the field

In addition to morphological observations and measurements made on the aerial parts of the cuttings (number of leaves formed, height), some measurements are carried out at the level of the root system formed at chrysanthemum cuttings (Table 7, Figure 9).

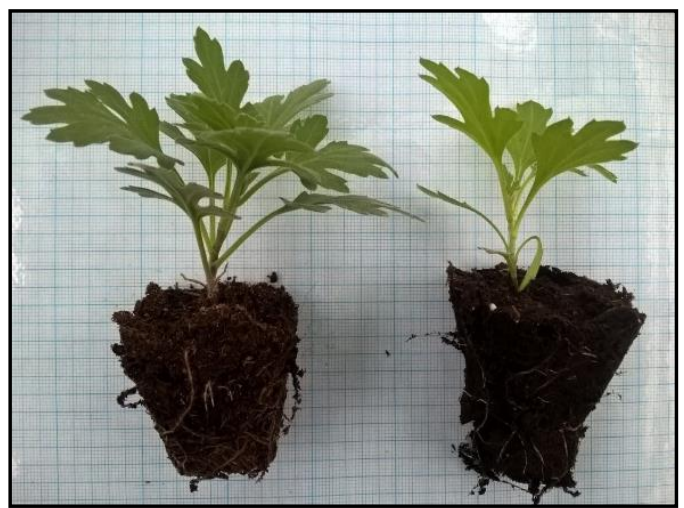

Figure 9. The root system of Chrysanthemum cuttings developed in the substrate (substrate volume $-60 \mathrm{ml}$ )

The total length of the roots of the cuttings was calculated using the intersected lines method, the root length of a sample being estimated using the intersection counting techniques of a given line system [NEWMAN, 1966; TENNANT, 1975]. The method proposed by Newman is based on the relationship between the root length and the number of 
Ana COJOCARIU \& Cătălin TĂNASE

intersections between the roots as a system of lines spread over a well-defined surface, and arranged randomly with the known length lines in the given area. With greater attention, one can obtain coefficients of variation of the estimation of the root length of $5 \%$ or even less [TENNANT, 1975], this being the minimum possible error.

Table 7. The total length of the developed roots at chrysanthemum cuttings (SFLAB), expressed in $\mathrm{cm}$ - Chrysanthemum indicum 'Carmina' (I) and Chrysanthemum $\times$ grandiflorum 'Yellow Stardust' (II)

\begin{tabular}{|c|c|c|c|c|}
\hline \multirow{2}{*}{ I } & pt & $p t+p$ & $p t+p+s$ & p \\
\hline & \multicolumn{4}{|c|}{ Root length / cutting - cm (Newman formula) } \\
\hline $\mathrm{A}(\mathrm{cm})$ & $34,01 \pm \mathrm{SD}$ & $35,20 \pm \mathrm{SD}$ & $35,72 \pm \mathrm{SD}$ & $31,71 \pm \mathrm{SD}$ \\
\hline $\mathrm{D}\left(\mathrm{m} / \mathrm{m}^{3}\right)$ & 5,67 & 5,86 & 5,95 & 5,28 \\
\hline$* \mathrm{SD}$ & $* 3,71$ & $* 3,09$ & $* 3,28$ & $* 3,37$ \\
\hline \multirow{2}{*}{ II } & pt & $p t+p$ & $p t+p+s$ & p \\
\hline & \multicolumn{4}{|c|}{ Root length / cutting - cm (Newman formula) } \\
\hline $\mathrm{A}(\mathrm{cm})$ & $33,44 \pm \mathrm{SD}$ & $31,19 \pm \mathrm{SD}$ & $30,53 \pm S D$ & $32,28 \pm \mathrm{SD}$ \\
\hline $\mathrm{D}\left(\mathrm{m} / \mathrm{m}^{3}\right)$ & 5,57 & 5,20 & 5,09 & 5,38 \\
\hline$* \mathrm{SD}$ & $* 2,99$ & $* 3,54$ & $* 3,57$ & $* 3,18$ \\
\hline
\end{tabular}

The root system of plants is in contact with a variety of abiotic factors, including soil water and nutrient availability, which influence both primary root growth and lateral root formation [INGRAM \& MALAMY, 2010]. These factors are constantly changing, and the ability of a plant to respond at these changes and effectively acquire the necessary water and nutrients has a direct impact on reproductive health and success.

\section{Conclusions}

The growing demand for competitive floriculture planting material, both on the national and international markets, has led to the adoption of new, modern and efficient technologies for the production of planting material.

The obtained data indicated differences according to variety, in the sense that the cuttings of Chrysanthemum indicum 'Carmina' formed new shoots much faster (average range of 15-21 days), compared with those of Chrysanthemum $\times$ grandiflorum 'Yellow Stardust' (average 21-27 days). The 100\% perlite as a substrate variant has shown the best efficiency regarding the emergence of new shoots in SFLAB cuttings. Based on the observations it can be concluded that the new method is recommended to obtain the planting material faster, but in order to obtain the lots more efficient and uniform, it is recommended mixture of perlite with peat $(\mathrm{p}+\mathrm{pt})$. According to the stem level for cuttings sampling, in the case of the top of the shoots (SUP), the rooting percentage was over $97 \%$, followed by the medium level with $93 \%$, while the cuttings made from the base of the shoots have rooted only in a proportion of $81 \%$ (INF).

By the new tested technique, for the manufacture of chrysanthemum cuttings using stem fragment with one leaf and axillary bud - SFLAB, 8-9 new plants can be obtained from a single basal shoots up to $10 \mathrm{~cm}$ in length, as opposed to the traditional method of propagation, which would produce only one plant per shoot, so an improved cuttings yield of over $8 \%$. The new method for obtaining rooted cuttings is new, simple, fast, and efficient in terms of time required but also economically. This method is especially recommended 


\section{DEVELOPMENT AND TESTING A NEW TECHNOLOGY FOR PRODUCTION OF...}

when there are small quantities of propagating material (stock-plant) and when the variety has a low capacity to develop shoots, which leads to obtaining more rooted cuttings, as a planting material for chrysanthemums.

At studied chrysanthemums varieties, the cuttings methods showed very good results, and the obtained planting material is of good quality and uniformity after the stage of transplantation into pots. As a general recommendation, it is concluded that the method of cutting using stem fragment with one leaf and axillary bud - SFLAB is very efficient, increasing the yield of planting material, by relating the number of rooted cuttings to the number of shoots collected from the mother plant.

\section{Notes on contributors}

Ana COJOCARIU - plant biologist, $\mathrm{PhD}$ with a special interest in ornamental plants cultivation, and work as coordinator of activities into Chrysanthemum Collection Section of Botanical Garden Iaşi - Romania. Areas of competence are also represented by ex situ conservation of economically important plants, fungal ecology - the study of stationary conditions that affect the diversity of lignicolous macromycetes species.

Cătălin TĂNASE - Professor PhD. at the Faculty of Biology of "Alexandru Ioan Cuza" University of Iaşi - Romania, Director of the Botanical Garden of Iasi, with competences in Botany, Conservation of Plant and Fungi Diversity, management of protected areas, culture conditions optimization for growing fungi in situ and ex situ, isolation of fungi with application in bioremediation, phytopathology-structural, physiological and biochemical modifications, produced by pathogen fungi.

\section{References}

ACOSTA M., OLIVEROS-VALENZUELA M. R., NICOLAS C. \& SANCHEZ-BRAVO J. 2009. Rooting of carnation cuttings: the auxin signal. Plant Signaling \& Behavior. 4(3): 234-236. doi:10.4161/psb.4.3.7912

ALI F. 2010. Use of vegetation for slope protection: Root mechanical properties of some tropical plants. International Journal of Physical Sciences. 5(5): 496-506.

CLARK D. G., GUBRIUM E. K., BARRETT J. E., NELL T. A. \& KLEE H. J. 1999. Root formation in ethyleneinsensitive plants. Plant Physiology. 121(1): 53-60. https://doi.org/10.1104/pp.121.1.53

DA COSTA C. T., DE ALMEIDA M. R., RUEDELL C. M., SCHWAMBACH J., MARASCHIN F. S. \& FETTNETO A. G. 2013. When stress and development go hand in hand: main hormonal controls of adventitious rooting in cuttings. Frontiers in Plant Science. 4: Article 133. https://doi.org/10.3389/fpls.2013.00133

GOUBRAN F. H. \& RICHARDS D. 1979. The estimation of root length in samples and sub-samples. Comparison of a visual and an automatic method. Plant and Soil. 52: 77-83.

INGRAM P. A. \& MALAMY J. E. 2010. Root System Architecture, pp. 75-117. In: KADER J.K., DELSENY M. (Eds.). 2010. Advances in Botanical Research, vol. 55.

JOTHI L. J., NANJAN K., CHEZHIYAN N. \& KHADER M. A. 1987. Influence of propagules, medium and season on rooting of chrysanthemum cuttings. South Indian Horticulture. 35(3): 220-225.

KHER M. A. 1976. Different rooting media effecting the rooting of chrysanthemum. Indian Journal of Ornamental Horticulture. 7: 36-39.

LAZĂR M. \& CACHIŢĂ-COSMA D. 1982. Micropropagarea la crizanteme prin culturi de ţesuturi Micropropagation in Chrysanthemum through tissue culture (in Romanian). Culegere de Studii şi Articole de Biologie, Iaşi. 2: 456-461.

LAZĂR M., CACHIŢĂ-COSMA D. \& BADER S. M. 1981. Micromultiplicarea la crizanteme. I. Înmulţirea „,in vitro" a crizantemelor prin explante de peduncul floral - The in vitro propagation of chrysanthemums by floral peduncle explant (in Romanian). Prod. Veg. Horticultura. 12: 18-23.

LIAO W. B., XIAO H. L. \& ZHANG M. J. 2010. Effect of Nitric Oxide and Hydrogen Peroxide on adventitious root development from cuttings of ground-cover Chrysanthemum and associated biochemical changes. Journal of Plant Growth Regulation. 29(3): 338-348. https://doi.org/10.1007/s00344-010-9140-5 
LIU R., CHEN S., JIANG J., ZHU L., ZHENG C., HAN S., GU J., SUN J., LI H., WANG H., SONG A. \& CHEN F. 2013. Proteomic changes in the base of chrysanthemum cuttings during adventitious root formation. BMC Genomics. 14: 919, 14 pp., http://www.biomedcentral.com/1471-2164/14/919

NEWMAN E. I. 1966. A method for estimating the total length of root in a sample. Journal of Applied Ecology. 3: 139-145.

PAGNUSSAT G. C., SIMONTACCHI M., PUNTARULO S. \& LAMATTINA L. 2002. Nitric oxide is required for root organogenesis. Plant Physiology. 129(3): 954-956. https://doi.org/10.1104/pp.004036

PETRUŞ-VANCEA A. \& CACHIŢĂ-COSMA D. 2013. New methods in vitroplantlets acclimatization. Romanian Biotechnological Letters. 18(5): 8689-8696.

PETTER S. 1992. More marketable plants in a shorter time. Gartenbau Magazin. 1(6): 68-70.

ROUT G. R. \& DAS P. 1997. Recent trends in the biotechnology of Chrysanthemum: a critical review. Scientia Horticulturae. 81(3-4): 201-228.

RUEDEll C., AlMeIDA M., SCHWAMBACH J., POSENATO C. \& FETT-NETO A. 2013. Pre and postseverance effects of light quality on carbohydrate dynamics and microcutting adventitious rooting of two Eucalyptus species of contrasting recalcitrance. Plant Growth Regulation. 69(3): 235-245. https://doi.org/10.1007/s10725-012-9766-3

SHIBUYA K., BARRY K. G., CIARDI J. A., LOUCAS H. M., UNDERWOOD B. A., NOURIZADEH S., ECKER J. R., KLEE H. J. \& CLARK D. G. 2004. The central role of PhEIN2 in ethylene responses throughout plant development in petunia. Plant Physiology. 136(2): 2900-2912. https://doi.org/10.1104/pp.104.046979

SHINOYAMA H., ANDERSON N., FURUTA H., MOCHIZUKI A., NOMURA Y., SINGH R. P. et al. 2006. Chrysanthemum biotechnology. In: J. A. TEIXEIRADA SILVA(ed.) Floriculture, Ornamental and Plant Biotechnology: Advances and Topical Issues (Volume I, $1^{\text {st }}$ Edition), Global Science Books, Ltd., Isleworth, UK: 140-163.

SINGH P. \& CHETTRI R. 2013. A new propagation method for rapid multiplication of chrysanthemum under in vivo conditions. International Journal of Conservation Science. 4(1): 95-100.

TEIXEIRA DA SILVA J. A. 2003. Chrysanthemum: advances in tissue culture, postharvest technology, genetics and transgenic biotechnology. Biotechnology Advances. 21: 715-766.

TEIXEIRA DA SILVA J. A. 2004. Ornamental chrysanthemums: improvement by biotechnology. Plant Cell, Tissue and Organ Culture. 79: 1-18.

TEIXEIRA DA SILVA J. A., SHINOYAMA H., AIDA R., MATSUSHITA Y., RAJ S. K. \& CHEN F. D. 2013. Chrysanthemum biotechnology: Quo vadis? Critical Reviews. Plant Sciences. 32(1): 21-52.

TENNANT D. 1975. A test of a modified line intersect method of estimating root length. Journal of Ecology. 63(3): 995-1001.

THE PLANT LIST. 2014. Chrysanthemum $\times$ grandiflorum Ramat. In: The plant list. A working list of all plant species. http://www.theplantlist.org/tpl1.1/record/gcc-144228. Accessed: 15 July 2019.

THE PLANT LIST. 2014a. Chrysanthemum indicum L. In: The plant list. A working list of all plant species. http://www.theplantlist.org/tpl1.1/record/gcc-139655. Accessed: 15 July 2019.

How to cite this article:

COJOCARIU A. \& TĂNASE C. 2019. Development and testing a new technology for production of Chrysanthemums planting material (Chrysanthemum s.1.). J. Plant Develop. 26: 93-107. https://doi.org/10.33628/jpd.2019.26.1.93 